Chirurgia (2017) 112: 413-417

No. 4, July - August

Copyright@ Celsius

http://dx.doi.org/10.21614/chirurgia.112.4.413

\title{
Hormone Therapy in Breast Cancer
}

\author{
Mădălina Drăgănescu, Codruța Carmocan \\ "Prof. Dr. Al.Trestioreanu" Institute of Oncology, Bucharest, Romania
}

Corresponding author:

Mădălina Drăgănescu, MD

"Prof. Dr. Al.Trestioreanu" Institute

of Oncology, Bucharest, Romania

E-mail: madalina.draganescu@gmail.com

\section{Rezumat \\ Hormonoterapia în cancerul mamar}

Hormonoterapia este obligatorie pentru toate pacientele cu neoplasm mamar cu receptori hormonali prezenți. Ea este activã atât în adjuvantã cât şi în boala metastaticã. Singurul tratament hormonal adjuvant activ în pre- şi postmenopauzã este Tamoxifen. Durata tratamentului adjuvant influențeazã intervalul liber de boalã, riscul apariției unui neoplasm mamar controlateral cât şi durata suprviețuirii. Inhibitorii de aromatazã: Anastrozol, Letrozol, Exemestan se folosesc numai în post menopauzã. În boala recurentã dupã sau în timpul tratamentului cu Tamoxifen se foloseşte Fulvestrant. Analogii LHRH se folosesc în premenopauzã în adjuvantã în anumite condiții, uneori în cazul recurentelor. Aproximativ 50\% din neoplasmele mamare cu receptori hormonali prezenți sunt sau devin rezistente la hormonoterapie. Molecule implicate în anumite cãi de creştere celularã tumoralã reverseazã rezistența la hormonoterapie (Palbociclib, Everolimus).

Cuvintele cheie: Tamoxifen, Anastrozol, Letrozol, Exemestan, Fulvestrant, Analogii LHRH, Palbociclib, Everolimus

\begin{abstract}
Hormonal therapy is mandatory for all patients with hormonereceptor-positive breast neoplasms. It is active both in adjuvant and metastatic disease. The only active adjuvant hormonal therapy in pre- and postmenopause is Tamoxifen. The adjuvant treatment duration influences disease-free survival, the risk of a contralateral breast cancer apparition and overall survival. The aromatase
\end{abstract}


inhibitors: Anastrozol, Letrozol, Exemestan are only used in postmenopause. Fulvestrant is used in recurrent disease after or during treatment with Tamoxifen. LHRH analogues are used in premenopausal patients in adjuvantcy and sometimes in case of recurrences. Around $50 \%$ of hormonereceptor-positive breast neoplasms are or become resistant to hormone therapy. Some molecules involved in some tumour cellular growth pathways reverse the resistance to hormone therapy (Palbociclib, Everolimus).

Key words: Tamoxifen, Anastrozol, Letrozol, Exemestan, Fulvestrant, LHRH analogues, Palbociclib, Everolimus

\section{Introduction}

Breast cancer treatment includes local therapies: surgery, radiotherapy and systemic: chemotherapy, hormonal therapy, targeted therapy.

The choice of systemic therapy is made depending upon the recurrence risk established through the prognosis score for each patient.

DNA studies led to the identification of an "intrinsic list" of over 500 genes which define 5 biological subtypes of breast cancer: luminal A, luminal B Her2 -, luminal B Her2 +, Non luminal Her2+, basal-like.

Nowadays, there are several multigene prognostic tests commercially available: Oncotype Dx(21), Mamaprint, Heredigen. The test results assign a low, intermediate or high recurrence risk. In 2009, at the breast cancer conference in San Antonio, it was established that the prognostic score obtained through immunohistochemistry testing of ER, PR, Her2/neu and Ki67 (IHC 4) is concordant to those offered by the genetic tests. In everyday practice we use IHC 4.

The patients with a low recurrence score benefit from hormone therapy, while chemotherapy is mandatory for patients with high recurrence score. For patients having an inter- mediate recurrence score, the systemic therapy chosen takes into account risk factors like: age, tumour size, tumour differentiation degree, the extension of lymph nodes invasion.

Intrinsic groups of breast cancer - Table 1 .

The nuclear receptors for estrogens and progesterone have an important role for the growth and differentiation of the normal mammary gland epithelium, and their expression in breast cancer is the most important predictive factor of the therapeutic response. Also, into a smaller extent, it is a prognostic factor.

\section{Her 2}

Her 2 is a molecule involved in the cellular proliferation, present on the surface of normal mammary gland epithelium cells and over expressed by approximately $20 \%$ of breast cancers, which determines their genomic instability and excessive proliferation. Currently, Her2 expression is considered to be the most important prognostic factor in breast cancer.

We ought to mention BRCA1 and BRCA2, suppressor genes involved in cellular response to DNA alterations. The inherited mutations of these genes are associated to a high risk of

Table 1.

\begin{tabular}{|c|c|c|c|c|c|}
\hline ER & + & + & + & - & - \\
\hline PR & $+>20 \%$ & $<20 \%$ & anyway & - & - \\
\hline Ki67 & $<20 \%$ & $>20 \%$ & anyway & anyway & anyway \\
\hline \multirow[t]{2}{*}{ Her2/neu } & - & - & + & + & - \\
\hline & Luminal A like & Luminal B like Her 2 - & Luminal B like Her $2+$ & Nonluminal Her + & Basal like \\
\hline
\end{tabular}


breast / ovary cancer emergence $(1,2,3)$. Even if breast cancer associated to BRCA 1 mutation is most often triple negative, oophorectomy reduces the risk of breast cancer with $50 \%$ in the case of mutant BRCA1 bearers; chemoprevention with Tamoxifen in patients with BRCA1 and BRCA2 mutations and breast cancer reduces the risk of developing collateral breast cancer by $50 \%$ and enhances survival.

The hormonal treatment in breast cancer is addressed to patients whose tumours express hormone receptors $(\mathrm{HR}+)$, for estrogens $(\mathrm{ER}+)$, for progestrone $(\mathrm{PR}+)$, or for both. Hormonal therapy may be administrated in neoadjuvant, adjuvant and metastatic disease.

The inventor of hormone therapy, Sir Thomas Beatson, was a surgeon who in 1896 presented the data obtained on a series of patients with advanced breast cancer, noticing that survival had been better in patients who had had oophorectomy, and recommended this procedure as palliative care for advanced breast cancer.

The estrogen receptor, with the two isoforms $a$ and $B$, has a role in developing normal mammary gland epithelium but also in devel- oping a breast cancer (approximately 70\% of breast cancers overexpress ER).

\section{$\boldsymbol{E R}$}

$\mathrm{ER}$ is a nuclear transcription factor. ER $\alpha$ and $\mathrm{ER}$ $B$ are coded by different genes. ER $\alpha$ is most frequently associated with breast cancer, with two transcription activating domains $(\mathrm{AF})$.

Ligand (estrogen) + ER: polymerisation, activation of AF1, AF2 $\rightarrow$ intranuclear DNA $\rightarrow$ estrogen-dependent gene activation ER also has a zone which activates ligand-independent transcription, which determines "cross-talk" with others pathways of cellular proliferation after phosphorylation, like mTor.

\section{PR}

PR is coded by an estrogen-dependent gene.

The fluctuation of $\mathrm{PR}$ presence in breast cancer cells has a prognostic and predictive value (4); ER+, PR+ breast cancer has a better response to antiestrogen therapy (50-70\%) than the ER + PR- $(30 \%)$.

\section{Hormone Therapy}

Hormonal therapy has the purpose of preventing the interaction between estrogens and estrogendependent pathways of stimulating neoplastic cells. It can be performed through:

1. Blocking the production of estrogens:

- ovarian inhibition:

- surgical (oophorectomy);

- radiological;

- chemical (LH-RH analogues);

- aromatase inhibitors (conversion enzyme of androgens precursors in estrogens).

2. Blocking the estrogens action upon tumour cells:

- SERM - act as estrogen agonists, antagonists or both, depending on the tisular target: Tamoxifen, Toremifen, Raloxifen;

- SERD - inhibition of ER activity: fulvestrant, ER antagonist without estrogen agonist effects.

The LH-RH analogue used in current practice is goserelin 3,6 mg, intradermal at 28 days.

The aromatase inhibitors currently used are 3rd generation non-steroidal aromatase inhibitors (reversible): Anastrozol $1 \mathrm{mg} /$ day p.o and Letrozol $2,5 \mathrm{mg} /$ day p.o or steroidal (irreversible): Exemestan $25 \mathrm{mg} /$ day p.o. Active only in postmenopausal patients. There is no crossed resistance between the two types of aromatase inhibitors.

Tamoxifen is the SERM the most used, active in pre and postmenopause in the dose of $20 \mathrm{mg} /$ day p.o; the response to Tamoxifen varies depending on the ER and PR percent from the HR+ breast cancer cells. The benefit of Tamoxifen therapy continues after the termination of treatment (5) and is independent and additive to the benefit of chemotherapy. It acts as estrogen antagonist in HR+ breast cancer cells, partially estrogen agonist in endometrial cells and estrogen agonist in bone cells. Oxford Review (2005-5) of randomized clinical trials showed that the adjuvant therapy 
with Tamoxifen for five years decreases the risk of recurrence by $41 \%$, and the risk of death due to beast cancer by $34 \%$, compared to non Tamoxifen; at a follow-up after 15 years the mortality of patients who received 5-year treatment with Tamoxifen was by $30 \%$ lower than in patients who received a 2 -year treat- ment with Tamoxifen. Also, 5 years of adjuvant therapy with Tamoxifen determined the decrease by $47 \%$ of collateral breast cancer risk. The benefit was proven for both patients with lymph nodes invasion (global survival at 10 years with 10\% better than non Tamoxifen) and without lymph nodes invasion (global survival at 10 years with $6 \%$ better).

The side effects of Tamoxifen treatment, which could limit to a certain extent its use, include the endometrium neoplasm, uterine sarcoma and the thromboembolic risk. A good monitoring of the treatment is mandatory: usually the gynaecologic examination, BabesPapanicolaou citological examination, transvaginal U/S.

SERD Fulvestrant, an injectable antiestrogen is more active in postmenopause than in premenopause and it is indicated in the case of disease progression during or after Tamoxifen. Dosing schedule: 2 x $250 \mathrm{mg}$ i.m monthly with an extra dose at 15 days in the first month.

Neoadjuvant hormone therapy is indicated in HR+ "low-grade" locally advanced breast cancer, or in patients with comorbidity / age which do not allow administration of chemotherapy.

Adjuvant hormone therapy is indicated in all patients with $\mathrm{HR}+$ breast neoplasm. It is not recommended to be administered concomitant to chemotherapy, but it can be administered during radiotherapy. In premenopause it consists of Tamoxifen +/- surgical / chemical ovarian inhibition. Ovarian inhibition is efficient as compared to therapeutic abstention (6). It is equivalent to CMF chemotherapy and can replace it. It is also indicated for premenopausal patients who did not become amenorrheic after chemotherapy (7). It decreases the recurrence risk with $6 \%$ and the death risk due to breast cancer with $6.3 \%$. Unlike surgical or radiological inhibition, the chemical ovarian inhibition is not definitive, which is an advantage in young patients, whose fertility is preserved. For now, no clear benefit was proven for associating LH-RH analogues treatment to Tamoxifen in adjuvant disease, but according to the consensus in Lisbon (2011), it is recommended to use the association of LH-RH analogues in the first two years of treat- ment in patients under 35 years old with HR+ breast neoplasm, who undergo adjuvant treatment with Tamoxifen (the first two years represent the period with the highest incidence of local and/or distant recurrences in the natural history of a breast cancer). In post-menopausal patients, the adjuvant hormonal therapy is Tamoxifen or aromatase inhibitors (8). Adjuvant therapy with aromatase inhibitors is indicated from the beginning in "high risk" patients (for example Her2+, important lymph nodes invasion) or in patients with counterindication for Tamoxifen through comorbidity. There are studies which showed the benefit of adjuvant therapy in postmenopause with Tamoxifen 2-3 years, followed by Exemestan 3-2 years (9). Also, taking into consideration the long natural history of $\mathrm{HR}+$ breast cancer, where recurrences often appear between years $6-15$, there are clinical studies which showed the bene- fit of adjuvant treatment with an aromatase inhibitor for 5 years, after a 5-year period of Tamoxifen adjuvant treatment. (10)

According to the same consensus in Lisbon in 2011, in case of HR+ metastatic breast cancer hormonal therapy is "the first-line treatment even in case of visceral metastases if hormone therapy resistance is not suspected, or diseases progression is not too fast". Patients with HR+ metastatic cancer are eligible for hormone therapy if they had a significant on disease-free survival (DFS) and if they adjuvant hormonal therapy.

The purpose of the treatment is not curative, since metastatic breast cancer cannot be cured. In order to choose the optimal therapy the risk factors have to be evaluated:

1. disease risk factors:

- disease-free survival (DFS);

- previous treatments and the response to them;

- biological factors (HR, Her2); 
- tumour volume (the number and the site of metastases);

- the necessity of a rapid control of symptoms.

2. patient risk factors:

- preference;

- biological age;

- menopausal status;

- IP and comorbidity;

- socio-economical and psychological factors;

- available therapies.

In HR+ metastatic breast neoplasm all hormonal therapies seem to have equivalent efficacy. The duration of the first response to hormone therapy is 9-12 months. For eligible patients hormone therapy has to be administered sequentially (line 1, 2, 3), chemotherapy being recommended only if there is no response to hormone therapy.

Almost half of the patients with HR+ breast neoplasm have de novo or acquired resistance to hormone therapy, one of the resistance mechanisms to hormone therapy being the activation of mTor cellular pathway. S6 kinase beta-1, the substrate of mTor complex, phosphorylates the ligand-independent activator domain of ER. mTor Everolimus inhibitor blocks the reaction and can reverse the resistance to hormone therapy. Bolero 2 clinical trial proved that the association of Everolimus $10 \mathrm{mg} /$ day p.o with Exemestan $25 \mathrm{mg} /$ day p.o in patients with $\mathrm{HR}+$, Her 2- metastatic breast cancer in progression under a nonsteroidal aromatase inhibitor doubles progression-free survival (PFS) com- $^{-}$ pared to Exemestan alone.

Cyclin-dependent kinases 4 and 6, which regulate cellular growth and division are inhibited by Palbociclib. Clinical studies showed that hormone-naive patients with $\mathrm{HR}+$, Her2advanced breast cancer who received Palbociclib $125 \mathrm{mg} /$ day and Letrozol 2,5 mg/day, p.o had a PFS of 24.8 months as compared to 14.5 months for patients who received only Letrozol (Paloma 2), and patients with HR+, Her2 - metastatic breast neoplasm in progression under hormone therapy who received Palbocilib plus Fulvestrant had a PFS of 11.2 months compared to 4.8 months in patients who received only Fulvestrant (Paloma 3).

The examples above show that targeted therapy can influence the response to hormonal therapy of patients with HR+ breast neoplasm.

\section{Conclusion}

In conclusion I would like to quote Professor Gabriel Hortobagyi from MD Anderson Cancer Center: "Breast cancer is a conglomerate of molecularly defined multiple syndromes, which are different as to their natural history, clinical evolution and sensitivity to external therapeutic agents".

\section{References}

1. Chavez Mac Gregor M, Valera V. Metastatic Breast Cancer The MD Anderson Manual of Clinical Oncology. 2011;25:679-703.

2. Abeloff MD, Wolff AC, Webar BL, Zaks TZ, Sacchini V, Mc Cormick B. Cancer of the Breast Abeloff's Clinical Oncology. 2008;95:1875-1945.

3. King MC, Marks JN, Mandell JB. Breast and ovarian cancer risks due to inherited mutations in BRCA1 and BRCA2. Science. 2003;302(5645): 643-6.

4. Allegra JC, Lippman ME, Thompson EB, Simon R, Barlock A, Green L, et al. Estrogen receptor status: an important variable in predicting response to endocrine therapy in metastatic breast cancer. Eur J Cancer. 1980;16(3):32331

5. Early Breast Cancer Trialists' Collaborative Group (EBCTCG). Effects of chemotherapy and hormonal therapy for early breast cancer on recurrence and 15-year survival: an overview of the randomised trials. Lancet. 2005;365(9472):1687-717.

6. Jonat W, Kaufmann M, Sauerbrei W, Blamey R, Cuzick J, Namer M, et al. Goserelin versus cyclophosphamide, methotrexate, and fluorouracil as adjuvant therapy in premenopausal patients with node-positive breast cancer: The Zoladex Early Breast Cancer Research Association Study. J Clin Oncol. 2002; 20(24):4628-35.

7. Castiglione-Gertsch M, O'Neill A, Price KN, Goldhirsch A, Coates AS, Colleoni M. Adjuvant chemotherapy followed by goserelin versus either modality alone for premenopausal lymph node-negative breast cancer: a randomized trial. J Natl Cancer Inst. 2003;95(24):1833-46.

8. Dowsett M, Cuzick J, Ingle J, Coates A, Forbes J, Bliss J, et al. Meta-analysis of breast cancer outcomes in adjuvant trials of aromatase inhibitors versus tamoxifen. J Clin Oncol. 2010;28(3):509-18. doi: 10.1200/JC0.2009.23.1274. Epub 2009 Nov 30.

9. Rose C, Vtoraya O, Pluzanska A, Davidson N, Gershanovich M, Thomas R, et al. An open randomised trial of second-line endocrine therapy in advanced breast cancer. comparison of the aromatase inhibitors letrozole and anastrozole. Eur J Cancer. 2003;39(16):2318-27.

10. Coombes RC1, Hall E, Gibson LJ, Paridaens R, Jassem J, Delozier T, et al. A randomized trial of exemestane after two to three years of tamoxifen therapy in postmenopausal women with primary breast cancer. N Engl J Med. 2004;350(11):1081-92.

11. Goss PE, Ingle JN, Martino S, Robert NJ, Muss HB, Piccart MJ, et al. Randomized trial of letrozole following tamoxifen as extended adjuvant therapy in receptor-positive breast cancer: updated findings from NCIC CTG MA.17. J Natl Cancer Inst. 2005;97(17):1262-71. 